сокращении технологического цикла изготовления пальцев за счет формирования в заготовке свойств по геометрическим и механическим характеристикам на уровне конструкторских требований к пальцу. Применение калиброванной упрочненной методом ВУК ТМО заготовки пальцев траков гусеничной ленты позволяет [6]: сократить технологический цикл изготовления пальцев за счет исключения операций термической, механической обработки и правки на заводе-изготовителе, повысить твердость и пластичность материала, что обеспечивает увеличение износостойкости в 1,6 - 1,9 раза и долговечности пальцев в 7 - 9 раз (при одинаковом с серийными пальцами уровне рабочих напряжений).

Таким образом, из всех применяемых методов технологического повышения характеристик работоспособности абразивно-изнашиваемых деталей, ВУК ТМО является не только методом, обеспечивающим комплексное улучшение износостойкости и долговечности, но и снижающим трудоемкость изготовления широко распространенных в технике деталей этого класса.

\title{
Списокиспользуемыхисточниковинформации
}

1. Бернштейн М.Л., Займовский В.А., Капуткина Л.М. Термомеханическая обработка стали. - М.: Металлургия, 1983. - 480 с.

2. Шаврин О.И., Маслов Л.Н., Скворцов А.Н. Повышение характеристик работоспособности абразивноизнашиваемых деталей высокотемпературной упрочняюще-калибрующей термомеханической обработкой. //Контактная жесткость, износостойкость, технологическое обеспечение: Международная научно-техническая конференция, 23-24 октября 2003 г. Брянск, - Брянск, БГТУ, 2003, -с. 5-8.

3. Шаврин О.И., Маслов Л.Н., Трухачев А.В. и др. Исследование и разработка технологии производства калиброванной стали с термомеханическим упрочнением. - Сталь, 1981, №3, с. 75-78.

4. Маслов Л.Н., Шаврин О.И., Дементьев В.Б., Князев А.Г., Скворцов А.Н. Обеспечение геометрических показателей качества заготовок абразивно-изнашиваемых деталей, изготовленных с применением термомеханического упрочнения. - Заготовительное производство в машиностроении - №5, 2006. c.33-37.

5. Шаврин О.И., Скворцов А.Н., Маслов Л.Н. Технологические и математические модели термомеханической обработки проволоки, калиброванной стали и деталей машин с формированием наноструктуры и повышенных эксплуатационных характеристик. //Современные методические материалы и технологии: 11-я международная научно-техническая конференция, 23-27 июня 2015 г., г. Санкт-Петербург.

6. Маслов Л.Н., Трухачев А.В. Термомеханическая обработка конструкционной стали 38ХС для деталей, работающих в условиях абразивного изнашивания. //Трение и износ. -1988 . Т.9, вып. №5, -с. 910-918.

\section{Ткач В.В. \\ Интенсификация адсорбционных свойств противоизносных присадок за счет внешнего силового поля}

doi: $10.18411 / l j-28-02-2017-1-10$

Донеикая академия внутренних дел МВД ДНР (Донеикая Народная Республика, Донеик)

idsp: 000001:lj-28-02-2017-1-10

\section{Аннотация}

В материалах доклада рассматривается один из перспективных способов интенсификации адсорбционного процесса молекул противоизносных присадок путем применения внешнего электростатического поля, что позволит при эксплуатации двигателей создать условия эффективного формирования смазочного слоя на поверхностях трения, а значит существенно продлить их ресурс. обработка.

Ключевые слова: адсорбционный процесс, интенсификация, электростатическая

В технических системах, где используются жидкие смазочные материалы, их ресурс определяется основным физическим явлением - износ поверхностей трения. Износ главным образом зависит от свойств смазочной пленки. Такая пленка формируется на 
поверхностях трения благодаря наличию сил поля поверхности трения и наличии смазочной среды.

Главным образом адсорбционный процесс на поверхностях трения определяется структурой смазочного материала, в котором главную роль в процессе физической конкурентной адсорбции играют противоизносные присадки. Улучшение эксплуатационных свойств смазочной пленки на поверхностях трения возможно за счет интенсификации адсорбционного процесса.

Анализ научно-исследовательских работ в области состава и структуры используемых смазочных материалов показывает, что молекулы присадок, которые вводят в базовые масла, являются поверхностно-активными веществами, обладающими дипольным моментом за счет разнесения положительных и отрицательных зарядов.

Вследствие кинетических процессов такие молекулы взаимодействуют между собой и образуют различные надмолекулярные структуры.

Их формирование зависит от концентрации присадки в смазочных средах. Согласно изучению структуры смазочного среды на примере моторных масел установлено, что их концентрация в объеме масла достигает критического значения, что не способствует в полной мере выполнению ими своего функционального назначения.

Таким образом, для повышения эффективности адсорбционного процесса молекул присадок возникает необходимость предварительного разрушения надмолекулярных структур, то есть, условно говоря, оказание помощи силовому полю поверхности трения. Интенсифицировать адсорбционный процесс, возможно, несколькими способами, одним из перспективных как показал анализ научно-исследовательских работ, является использование внешнего электростатического поля.

С целью проверки теоретических разработок были проведены исследования по определению толщины смазочной пленки, согласно которым применение электростатической обработки позволило повысить адсорбционные свойства.

Так для моторного масла марки М-12Г2 толщина смазочной пленки выросла в 1,7 1,8 раза, а для смазки М-6з/12Г1 в 1,76 - 1,78 раза, в зависимости от температуры.

Полученный эффект позволил продлить ресурс автомобильной техники до двух раз по сравнению с традиционными вариантами эксплуатации.

\section{Списокиспользуемыхисточниковинформации}

1. Александров Е.Е., Кравец И.А., Лысиков Е.Н. и др. Повышение ресурса технических систем путем использования электрических и магнитных полей. Харьков: НТУ «ХПИ», 2005 - 544c. 